\title{
"First Do No Harm": Adverse Events from Pharmaceutical Treatment of Gastroparesis and Dyspepsia
}

\author{
Thomas M. Goodsall ${ }^{1,2} \cdot$ Nicholas J. Talley ${ }^{1,2}$
}

Published online: 20 September 2017

(C) Springer Science+Business Media, LLC 2017

Dyspepsia, a symptom that impacts at least $10 \%$ of Americans, can be troubling to disabling, impairing work and relationships [1]. Dyspepsia refers to a chronic or recurrent upper gastrointestinal symptom complex presumed to arise from the gastroduodenum rather than the esophagus; epigastric pain or discomfort, fullness after meals, or inability to finish a normal-sized meal (early satiety), and nausea with or without vomiting all are dyspeptic symptoms that can negatively impact the quality of life. If delayed gastric emptying accompanies these symptoms, a diagnostic label of gastroparesis is usually applied [2]. Many other underlying causes of dyspepsia need to be considered, from peptic ulceration including Helicobacter pylori infection to gastroesophageal reflux disease (GERD), biliary tract disease, and rarely esophagogastric cancers, but the most frequent explanation encountered in practice is functional dyspepsia [1].

Often misdiagnosed as GERD and treated with proton pump inhibitors (PPIs) with modest to no benefit [3], functional dyspepsia is common, with a prevalence of 5-11\% [1]. Functional dyspepsia according to the Rome IV diagnostic criteria [4] comprises postprandial distress syndrome (bothersome postprandial fullness or early satiety severe enough to impact on regular activities for 3 or more days per week in the past 3 months) or the epigastric pain syndrome (bothersome epigastric pain or epigastric burning 1 or more days per week in the past 3 months),

Nicholas J. Talley

Nicholas.talley@newcastle.edu.au

1 Faculty of Health and Medicine, University of Newcastle, Kookaburra Circuit, New Lambton, NSW, Australia

2 Gastroenterology Department, John Hunter Hospital, New Lambton, NSW, Australia although many patients complain of both syndromes [4]. Recent evidence has identified duodenal inflammation in functional dyspepsia, with a small but significant increase in eosinophils in the duodenal mucosa (and in some cases mast cells), most notably in subjects with early satiety and postprandial distress $[5,6]$.

Gastroparesis, a condition less common but more serious than functional dyspepsia, carries a significantly decreased 5-year survival rate of $67 \%$ compared to an ageand sex-adjusted control rate of $81 \%$ [7] and is estimated to affect 4 million Americans, of which up to $25 \%$ have diabetic neuropathy [8]. Gastroparesis is defined by upper gastrointestinal symptoms with evidence of delayed gastric emptying in the absence of mechanical gastric outlet obstruction [8]. Since one in four patients with functional dyspepsia has evidence of delayed gastric emptying consistent with mild-to-moderate gastroparesis [2], applying the correct label can be confusing. In functional dyspepsia, unlike gastroparesis, vomiting is not prevalent, and symptoms correlate poorly if at all with gastric emptying delay [1]; further, this disorder, unlike true gastroparesis, is not associated with any known increased mortality risk [9].

After appropriate diagnostic evaluation, functional dyspepsia may respond to simple management strategies including diet, lifestyle modifications, and stress reduction, but many patients experience ongoing symptoms that require escalation to drug therapy. Pharmacologic options include acid suppression, usually with a PPI, prokinetic agents including metoclopramide or domperidone, and, if these fail, an antidepressant with the best evidence of efficacy in the tricyclic antidepressant class [10]. Since these disorders likely have multiple underlying etiologies and are associated with depression, anxiety or somatization, therapy is complicated by the difficulties inherent in predicting likely responders to a specific therapy, and the 
modest therapeutic gain over placebo [1, 10]. Although gastroparesis is usually managed with dietary advice (small frequent low fat, low-fiber meals, and if needed splitting solids and liquids), prokinetic and anti-nausea drugs, and, if applicable, tight glycemic control, many cases are refractory to pharmacologic therapy. In the minority of cases, gastroparesis is severe enough for interventional implantable gastric electrical stimulation therapy, a therapy that reduces vomiting frequency [8].

The chronic nature of dyspepsia and gastroparesis combined with the potential risks of pharmaceutical management raises the question of whether attempts to treat patients are causing more harm than good. In this issue of Digestive Diseases and Sciences, Bielefeldt has taken a novel approach to quantifying iatrogenic complications in a retrospective adverse event database study of gastroparesis or dyspepsia [11]. This study extracted all reports of adverse events associated with treatment of dyspepsia or gastroparesis from the Federal Adverse Event Reporting System (FAERS) over an 11-year period [11], with the aim of describing the trends in medication use and associated adverse events. The authors identified 1245 and 21,243 reports listing gastroparesis or dyspepsia, respectively; the demographics of these reports mirrored published epidemiologic factors with a female predominance and mean age in the sixth decade $[1,8]$. It is unclear whether FAERS reports associated with treatment of dyspepsia refer to the syndrome of functional dyspepsia or with isolated dyspepsia, a symptom commonly accompanying gastroesophageal reflux disease $[1,3]$. This distinction remains important globally since treatment of functional dyspepsia can include the use of the few prokinetic agents available for functional dyspepsia, including, metoclopramide, a drug that is not generally recommended [12]. Reports in which gastroparesis was the treatment indication included concurrent hypoglycemic agents in 29\% [11] consistent with the predicted prevalence of diabetes mellitus [8].

Adverse events related to the treatment of dyspepsia in the FAERS database were most commonly associated with acid suppression followed by those associated with metoclopramide, whereas this order was reversed for events related to the treatment of gastroparesis [11]. Most reports were lodged by the customer in dyspepsia cases $(51 \%)$, but in gastroparesis, legal workers were the most common reporter in $39 \%$ of cases, skewed by a $4000 \%$ transient increase in reporting of tardive dyskinesia due to metoclopramide in 2011 of which $98 \%$ originated from legal sources in relation to a class action [11]. This represents a reporting bias with potential financial incentives. Other data suggest tardive dyskinesia from metoclopramide has an estimated incidence of $<0.1 \%$ among those prescribed the drug, with a dose-related risk [13].
Tardive dyskinesia is an important and significant adverse effect of metoclopramide use. Although over-represented and skewed in the FAERS data, the results should prompt clinicians to be mindful of the risks and adhere to the FDA-recommended therapy duration of up to 12 weeks. Clinicians outside of the USA need to interpret this in the context of the availability of other prokinetic agents with less central dopamine antagonism such as domperidone. More generally, patients with gastroparesis or dyspepsia should be regularly reassessed and considered for a "drug holiday." It is important when prescribing metoclopramide to always warn the patient of the potential risk of tardive dyskinesia, as stopping the drug does not reverse the disease in half of affected cases, and to use the lowest effective dose for no longer than 12 weeks [13].

There is a growing concern about the use of PPIs, especially in younger patients, with anecdotally many patients now asking their physician to cease the treatment following media reports of potentially serious adverse effects. Acid-suppressing medications in the Bielefeldt study were implicated in $10 \%$ of 1944 reports of neurological side effects, $24 \%$ of 211 reports of myocardial infarction and stroke, $84 \%$ of 257 reports of osteoporosis and $50 \%$ of 135 reports of renal failure [11]. Reports of adverse effects due to PPIs do not support a true causal relationship. Although a critical review of the relevant literature does demonstrate associations between PPIs and serious skeletal, renal, gastrointestinal, and neurological events, these findings are based on epidemiological evidence. In Table 1, a summary of the criteria proposed by Bradford Hill for assessing causality and the association between PPIs and adverse events are presented; much of the data are weak and potentially subject to major bias including confounding [14-19]. Notably, no reports of hypomagnesemia due to acid-suppressing medications were described by Bielefeldt, despite this being a recognized adverse effect of PPI, probably due to its extreme rarity [20].

Histamine 2 receptor antagonists $\left(\mathrm{H}_{2} \mathrm{RAs}\right)$, a small portion of claims implicating acid suppression, were mostly associated with concerns of limited or absent efficacy, or a false-positive drug screen. A meta-analysis based on older studies suggested that $\mathrm{H}_{2} \mathrm{RA}$ therapy is efficacious in functional dyspepsia [21], of interest as more recently duodenal eosinophilia and increased mast cells (that may release histamine) $[5,6]$ or duodenal changes in the microbiome that might release excess histamine [22] suggest that antagonizing histamine might do more good than just reduce gastric acid secretion [1]. Histamine antagonism may thus be an alternative therapy in functional dyspepsia with equal efficacy and lower risk of adverse events than with other drugs. 
Table 1 Reported complications of proton pump inhibitor (PPI) use and assessment of the strength of evidence using the Bradford Hill criteria and summary of Oxford Centre for Evidence-Based Medicine (OCEBM) level of evidence [25]

\begin{tabular}{|c|c|c|c|c|c|}
\hline \multirow{2}{*}{$\begin{array}{l}\text { Determinant } \\
\text { of causality } \\
\text { criteria }\end{array}$} & \multicolumn{5}{|c|}{ Postulated adverse effect } \\
\hline & Dementia [14] & $\begin{array}{l}\text { Osteoporosis and fracture } \\
\text { [19] }\end{array}$ & Kidney disease [16] & $\begin{array}{l}\text { Gastrointestinal [18] } \\
\text { and prulmonary [15] } \\
\text { infection }\end{array}$ & Hypomagnesemia [17] \\
\hline $\begin{array}{l}\text { Strength of } \\
\text { association }\end{array}$ & $\begin{array}{l}\text { Adjusted hazard } \\
\text { ratio } 1.44 \\
(1.36-1.52) \\
P<0.001\end{array}$ & $\begin{array}{l}\text { Meta-analysis of } 244,109 \\
\text { fracture cases, moderate } \\
\text { increase in hip fracture } \\
\text { risk } \mathrm{RR}=1.26,95 \% \mathrm{CI} \\
1.16-1.36 . \text { Spine fracture } \\
\mathrm{RR}=1.58,95 \% \mathrm{CI} \\
1.38-1.82 . \text { Significant } \\
\text { heterogeneity }\end{array}$ & $\begin{array}{l}\text { Meta-analysis of } 2.6 \\
\text { million patients, } \\
\text { increased risk of AKI } \\
\mathrm{RR}=1.44,95 \% \mathrm{CI} \\
1.08-1.91), \mathrm{CKD} \\
\mathrm{RR}=1.36(95 \% \mathrm{CI} \\
1.07-1.72), \mathrm{AIN} \\
\mathrm{RR}=1.42(95 \% \mathrm{CI} \\
1.28-1.58)\end{array}$ & $\begin{array}{l}\text { Pneumonia meta- } \\
\text { analysis of } \\
6,351,656 \text { patients } \\
\text { in } 26 \text { studies. } \\
\text { Pooled RR = } 1.49 \\
\text { (95\% CI } 1.16-1.92) \\
\text { C difficile meta- } \\
\text { analysis of } 47 \\
\text { studies. Pooled OR } \\
1.65 \text { (95\% CI } \\
1.47-1.85)\end{array}$ & $\begin{array}{l}\text { Meta-analysis of } \\
115,455 \text { patients } \\
\text { from } 9 \text { retrospective } \\
\text { studies. Pooled } \\
\text { OR }=1.78(95 \% \text { CI } \\
1.07-2.92) \\
\text { Subject of less than } 1 \% \\
\text { of FDA reports of } \\
\text { PPI-associated } \\
\text { adverse events }\end{array}$ \\
\hline Consistency & $\begin{array}{l}\text { Not reproduced in } \\
\text { large human } \\
\text { studies }\end{array}$ & $\begin{array}{l}18 \text { international studies } \\
\text { included. All cohort or } \\
\text { case-control }\end{array}$ & $\begin{array}{l}9 \text { international studies, } \\
\text { high degree of } \\
\text { heterogeneity }\end{array}$ & $\begin{array}{l}\text { International studies, } \\
\text { high degree of } \\
\text { heterogeneity. High } \\
\text { likelihood of } \\
\text { publication bias for } \\
\text { C. difficile } \\
\text { infections }\end{array}$ & $\begin{array}{l}9 \text { international studies, } \\
\text { high degree of } \\
\text { heterogeneity }\end{array}$ \\
\hline Specificity & $\begin{array}{l}\text { Low, evidence } \\
\text { from } \\
\text { retrospective } \\
\text { prescribing } \\
\text { database }\end{array}$ & $\begin{array}{l}\text { Low, cohort and case- } \\
\text { control data with high } \\
\text { chance of confounding. } \\
\text { Ascertainment of } \\
\text { exposure especially } \\
\text { limited }\end{array}$ & $\begin{array}{l}\text { Low, cohort and case- } \\
\text { control data with high } \\
\text { chance of confounding. } \\
\text { Ascertainment of } \\
\text { exposure especially } \\
\text { limited }\end{array}$ & $\begin{array}{l}\text { Low, cohort and } \\
\text { case-control data } \\
\text { with high chance of } \\
\text { confounding. } \\
\text { Ascertainment of } \\
\text { exposure especially } \\
\text { limited }\end{array}$ & $\begin{array}{l}\text { Removal of PPI leads } \\
\text { to resolution in case } \\
\text { studies }\end{array}$ \\
\hline Temporality & $\begin{array}{l}\text { Time interval of } \\
6 \text { years or less } \\
\text { may be too short } \\
\text { for clinical } \\
\text { disease to occur }\end{array}$ & Heterogeneity in studies & $\begin{array}{l}\text { Follow-up time not } \\
\text { reported in many studies, } \\
\text { ranges from } 120 \text { days to } \\
14 \text { years }\end{array}$ & $\begin{array}{l}\text { Highest risk for CAP } \\
\text { reported in first } \\
30 \text { days after } \\
\text { initiation of therapy }\end{array}$ & $\begin{array}{l}\text { All cases preceded by } \\
\text { PPI use, short time } \\
\text { from exposure to } \\
\text { clinically apparent } \\
\text { disease }\end{array}$ \\
\hline $\begin{array}{c}\text { Biological } \\
\text { gradient }\end{array}$ & Not reported & $\begin{array}{l}\text { No difference between } \\
\text { short term }(<1 \text { year) or } \\
\text { long term }(>1 \text { year) use }\end{array}$ & $\begin{array}{l}\text { Some evidence of CKD } \\
\text { and AIN being dose } \\
\text { dependent }\end{array}$ & Not clear & $\begin{array}{l}\text { Not clear based on } \\
\text { available evidence }\end{array}$ \\
\hline Plausibility & $\begin{array}{l}\text { Possible vitamin } \\
\text { B12 deficiency } \\
\text { link and murine } \\
\text { model of PPI } \\
\text { induced beta- } \\
\text { amyloid } \\
\text { accumulation }\end{array}$ & $\begin{array}{l}\text { Calcium absorption is } \mathrm{pH} \\
\text { dependent }\end{array}$ & $\begin{array}{l}\text { AIN is thought to be } \\
\text { idiosyncratic and dose } \\
\text { dependent. The } \\
\text { development of CKD is } \\
\text { hypothesized to be due to } \\
\text { impaired endothelial } \\
\text { dysfunction and } \\
\text { subclinical AIN }\end{array}$ & $\begin{array}{l}\text { Acid suppression } \\
\text { leading to bacterial } \\
\text { overgrowth and } \\
\text { increased risk of } \\
\text { bacterial aspiration. } \\
\text { Gastric acid } \\
\text { suppresses C. } \\
\text { difficile vegetations } \\
\text { but not spores }\end{array}$ & $\begin{array}{l}\text { Idiosyncratic PPI or } \\
\text { pH-dependent } \\
\text { inactivation of active } \\
\text { magnesium } \\
\text { absorption channel } \\
\text { TRPM6/7 is } \\
\text { proposed mechanism }\end{array}$ \\
\hline Coherence & $\begin{array}{l}\text { Molecular-based } \\
\text { studies not yet } \\
\text { available }\end{array}$ & $\begin{array}{l}\text { PPI use does not appear to } \\
\text { affect BMD in a dose- } \\
\text { dependent way [24] }\end{array}$ & & $\begin{array}{l}\text { Weak and very low- } \\
\text { quality evidence }\end{array}$ & $\begin{array}{l}\text { Consistently } \\
\text { demonstrated in case } \\
\text { series and active } \\
\text { magnesium transport } \\
\text { channel implicated }\end{array}$ \\
\hline Experiment & $\begin{array}{l}\text { Retrospective } \\
\text { cohort studies }\end{array}$ & $\begin{array}{l}\text { Cohort studies and case- } \\
\text { control studies }\end{array}$ & $\begin{array}{l}\text { Cohort studies and case- } \\
\text { control studies }\end{array}$ & $\begin{array}{l}\text { Cohort studies and } \\
\text { case-control studies }\end{array}$ & $\begin{array}{l}\text { Cohort studies and } \\
\text { case-control studies } \\
\text { and active } \\
\text { magnesium transport } \\
\text { channel implicated }\end{array}$ \\
\hline
\end{tabular}


Table 1 continued

\begin{tabular}{|c|c|c|c|c|c|}
\hline \multirow{2}{*}{$\begin{array}{l}\text { Determinant } \\
\text { of causality } \\
\text { criteria }\end{array}$} & \multicolumn{5}{|c|}{ Postulated adverse effect } \\
\hline & Dementia [14] & $\begin{array}{l}\text { Osteoporosis and fracture } \\
{[19]}\end{array}$ & Kidney disease [16] & $\begin{array}{l}\text { Gastrointestinal [18] } \\
\text { and prulmonary [15] } \\
\text { infection }\end{array}$ & Hypomagnesemia [17] \\
\hline $\begin{array}{l}\text { OCEBM } \\
\text { level of } \\
\text { evidence or } \\
\text { GRADE } \\
\text { quality of } \\
\text { evidence }\end{array}$ & Level 4 & Level 3 & $\begin{array}{l}\text { Level } 3 \\
\text { GRADE = low for AKI } \\
\text { and CKD. Insufficient } \\
\text { quality for AIN }\end{array}$ & $\begin{array}{l}\text { Level 3-4 } \\
\text { GRADE = Very low } \\
\text { for } C \text {. difficile } \\
\text { infection }\end{array}$ & Level 3 \\
\hline
\end{tabular}

$R R$ relative risk, $C I$ confidence interval, $O R$ odds ratio, $C A P$ community-acquired pneumonia, $C K D$ chronic kidney disease, $A I N$ acute interstitial nephritis, GRADE grading of recommendations assessment, development, and evaluation

In the study by Bielefeldt, there were no FAERS reports of an adverse event associated with tricyclic antidepressants or with mirtazapine as treatments for dyspepsia. There are data to support the efficacy of low doses of tricyclic antidepressants and possibly mirtazapine in functional dyspepsia but not gastroparesis, especially in the epigastric pain syndrome subtype [10, 23]. The lack of FAERS reports may reflect the tolerability of low-dose treatment or a hesitancy among prescribers to use these therapies.

A total of $8 \%$ of submissions reported lack of treatment benefit as an undesired outcome, but as Bielefeldt rightly observes, this is not a true adverse effect, although it reflects the challenging and refractory nature of these disorders and is likely an underestimate [11].

When managing dyspepsia and gastroparesis, Bielefeldt demonstrates that common medications used for these often refractory and difficult-to-manage disorders carry a risk of adverse effects although the absolute risk cannot be estimated using these data. Regardless, the findings should prompt a return to first principles of management starting with an explanation to the patient and a trial of simple lifestyle modifications with establishment of realistic management goals. Where pharmacologic treatment is necessary, medications should be reviewed and "drug holidays" considered. If therapy is ineffective or adverse events become apparent, switching within or between classes of drugs is a reasonable clinical strategy.

\section{Key Messages}

- Gastroparesis and functional dyspepsia can impair quality of life; of the limited treatment options available, patients are often prescribed prokinetic agents or acid-inhibiting medications.

- In a review of the US Food and Drug Administration (FDA) reported adverse events, prokinetic agents were implicated in 57\% of adverse events related to the treatment of gastroparesis and in $40 \%$ of adverse events related to the treatment of dyspepsia.

- Tardive dyskinesia, the most commonly reported adverse event, was likely due to a reporting bias associated with legal claims from 2009 to 2013.

- Although proton pump inhibitors were the second most common drug implicated in several adverse event reports including myocardial infarction, stroke, osteoporosis, renal failure, and ineffective treatment, the causality of these associations is limited-nil.

- Clinicians should consider the potential risks of medications and the limited evidence for clinically significant benefit when managing patients with gastroparesis or dyspepsia.

\section{References}

1. Talley NJ, Ford AC. Functional dyspepsia. $N$ Engl J Med. 2016;374:896.

2. Sarnelli G, Caenepeel P, Geypens B, Janssens J, Tack J. Symptoms associated with impaired gastric emptying of solids and liquids in functional dyspepsia. $\mathrm{Am} J$ Gastroenterol. 2003;98:783-788

3. Pleyer C, Bittner H, Locke GR 3rd, et al. Overdiagnosis of gastroesophageal reflux disease and underdiagnosis of functional dyspepsia in a USA community. Neurogastroenterol Motil. 2014;26:1163-1171.

4. Stanghellini V, Chan FK, Hasler WL, et al. Gastroduodenal disorders. Gastroenterology. 2016;150:1380-1392.

5. Cirillo C, Bessissow T, Desmet AS, Vanheel H, Tack J, Vanden Berghe P. Evidence for neuronal and structural changes in submucous ganglia of patients with functional dyspepsia. Am J Gastroenterol. 2015;110:1205-1215.

6. Walker MM, Talley NJ. The role of duodenal inflammation in functional dyspepsia. J Clin Gastroenterol. 2017;51:12-18.

7. Jung HK, Choung RS, Locke GR 3rd, et al. The incidence, prevalence, and outcomes of patients with gastroparesis in Olmsted County, Minnesota, from 1996 to 2006. Gastroenterology. 2009;136:1225-1233. 
8. Stein B, Everhart KK, Lacy BE. Gastroparesis: a review of current diagnosis and treatment options. J Clin Gastroenterol. 2015;49:550-558.

9. Chang JY, Locke GR 3rd, McNally MA, et al. Impact of functional gastrointestinal disorders on survival in the community. Am J Gastroenterol. 2010;105:822-832.

10. Talley NJ, Locke GR, Saito YA, et al. Effect of amitriptyline and escitalopram on functional dyspepsia: a multicenter, randomized controlled study. Gastroenterology. 2015;149:340-349.

11. Bielefeldt K. From harmful treatment to secondary gain: adverse event reporting in dyspepsia and gastroparesis. Dig Dis Sci. (Epub ahead of print). doi:10.1007/s10620-017-4633-8.

12. Zala AV, Walker MM, Talley NJ. Emerging drugs for functional dyspepsia. Expert Opin Emerg Drugs. 2015;20:221-233.

13. Rao AS, Camilleri M. Review article: metoclopramide and tardive dyskinesia. Aliment Pharmacol Ther. 2010;31:11-19.

14. Gomm W, von Holt K, Thome F, et al. Association of proton pump inhibitors with risk of dementia: a pharmacoepidemiological claims data analysis. JAMA Neurol. 2016;73:410-416.

15. Lambert AA, Lam JO, Paik JJ, Ugarte-Gil C, Drummond MB, Crowell TA. Risk of community-acquired pneumonia with outpatient proton-pump inhibitor therapy: a systematic review and meta-analysis. PLoS ONE. 2015;10:e128004.

16. Nochaiwong S, Ruengorn C, Awiphan R, et al. The association between proton pump inhibitor use and the risk of adverse kidney outcomes: a systematic review and meta-analysis. Nephrol Dial Transplant. 2017;153:702-710.

17. Park $\mathrm{CH}$, Kim EH, Roh YH, Kim HY, Lee SK. The association between the use of proton pump inhibitors and the risk of hypomagnesemia: a systematic review and meta-analysis. PLoS ONE. 2014;9:e112558.

18. Tleyjeh IM, Bin Abdulhak AA, Riaz M, et al. Association between proton pump inhibitor therapy and clostridium difficile infection: a contemporary systematic review and meta-analysis. PLoS ONE. 2012;7:e50836.

19. Zhou B, Huang Y, Li H, Sun W, Liu J. Proton-pump inhibitors and risk of fractures: an update meta-analysis. Osteoporos Int. 2016;27:339-347.

20. Toh JW, Ong E, Wilson R. Hypomagnesaemia associated with long-term use of proton pump inhibitors. Gastroenterol Rep (Oxf). 2015;3:243-253.

21. Ford AC, Luthra P, Tack J, Boeckxstaens GE, Moayyedi P, Talley NJ. Efficacy of psychotropic drugs in functional dyspepsia: systematic review and meta-analysis. Gut. 2017;66:411-420.

22. Zhong L, Shanahan ER, Raj A, et al. Dyspepsia and the microbiome: time to focus on the small intestine. Gut. 2017;66: $1168-1169$.

23. Jiang SM, Jia L, Liu J, Shi MM, Xu MZ. Beneficial effects of antidepressant mirtazapine in functional dyspepsia patients with weight loss. World J Gastroenterol. 2016;22:5260-5266.

24. Targownik LE, Leslie WD, Davison KS, et al. The relationship between proton pump inhibitor use and longitudinal change in bone mineral density: a population-based study [corrected] from the Canadian Multicentre Osteoporosis Study (CaMos). Am J Gastroenterol. 2012;107:1361-1369.

25. Group OLoEW. The Oxford 2011 Levels of Evidence.. Oxford Centre for Evidence-Based Medicine. 2011. 